\title{
Evaluation of Sport Special Class (SSC) Program in High School Level at Gunungkidul Regency Yogyakarta
}

\author{
Nurhadi Santoso ${ }^{1}$, Tandiyo Rahayu ${ }^{2}$, Setya Rahayu ${ }^{3}$, Sugiharto ${ }^{4}$ \\ \{nurhadi_santoso@uny.ac.id ${ }^{1}$, tandiyorahayu@mail.unnes.ac.id ${ }^{2}$, setyarahayu@mail.unnes.ac.id ${ }^{3}$, \\ SGH@mail.unnes.ac.id $\left.{ }^{4}\right\}$ \\ ${ }^{1}$ Universitas Negeri Yogyakarta, ${ }^{2}$ Graduate School, Universitas Negeri Semarang
}

\begin{abstract}
This research aims to evaluate the implementation of a SSC in high school level at Gunungkidul Regency Yogyakarta with the CIPP model. This research is a type of program evaluation. The total subject of this research was 17 people. Research data was obtained through interviews, observations, and documentation. Data analysis technique used data triangulation. Research results can be summarized as follows: The implementation of SSC based on the decree from the Head of District Education Department and Provincial Education Department of Yogyakarta. Selection of new students for SSC is good. The budget comes from the provincial budget, School Operating Support, and school committees. The condition of the availability of limited equipment and field facilities is less supportive. The learning process uses the curriculum from the Education Office. The training process is carried out 2-4 times a week. Sports achievements at Gunungkidul district are good.
\end{abstract}

Keywords: evaluation, sport special class (SCC)

\section{Introduction}

National sport achievements that are less encouraging in principle and more or less illustrate the condition of sport developments at school and sport level has not been implemented properly, optimally, and programmed. Therefore, in order to optimize quality of students' sport achievements and empower schools, there needs to be supported by a program that can accommodate these activities in the form of sport classes so that schools can conduct better and continuous sport coaching [1]. Special classes for sports are classes specifically for students who have special excellences or talents in certain sports fields. In Australia since 1990, more than 200 sports schools have been established internationally [2]. Emrich, E. et al. states that elite sports schools in Germany are promotional facilities, in which collaborating with competitive sports, schools and all accommodation must ensure conditions that support top sports in the future while maintaining opportunities for primary and secondary education for assessed students very talented [3].

Nursery of potential athlete candidates is one effort to capture talented athletes and efforts to find individuals who have the potential to achieve high sport performance in the future [4]. Scouting from early age is done to estimate or predict chances of talented athlete, in order to succeed in running training program so that they can achieve peak performance [5]. Coaching and development in sport field achievement are done and directed towards achieving sport 
achievements at regional, national, and international levels [6]. Achievement of peak performance needs to be elaborated in a comprehensive concept in a tiered coaching system [7]. At the age of 16, when young people start going to school in secondary schools, they are allowed to choose programs and have opportunity to focus more on certain sports [8]. A comprehensive review has revealed various positive development experiences related to youth participation in sports [9].

Preparation of a training program that is good and measurable by the trainer will enable the training process to succeed well. If the opposite occurs, sports specialties associated with training with high volume can result in psychological stress and excessive injury [10]. On the other hand, high volume and intensity in sports activities make young athletes at higher risk of injury [11]. Trainers in special sports classes at the high school level must be able to develop training programs in accordance with the development and characteristics inherent in the special sports class students (athletes' students) they train

According to National Sport Committee of Indonesia, factors that support development process of sport achievement are professional coaches, sufficient infrastructure for training, training systems and methods, appropriate training programs, professional management, and supportive environment [12]. The development of sport achievements in SSC will not work well if it is not supported by professional coaches, sufficient infrastructure for training, training systems and methods, appropriate training programs, professional management, supportive environment and sufficient financial support. Schools have been considered attractive environment for practicing sports regarding that the most accessible learners and school sport programs can contribute to school's education mission [13]. The product of this research, the formation of an ideal SSC model in Gunungkidul Regency, Yogyakarta.

\section{Method}

The research was program evaluation research type. Program evaluation was focused on overall process of implementing SSC and achievements produced by SSC students in high school level at Gunungkidul Regency, Yogyakarta. Research evaluated SSC programs in Gunungkidul Regency refers to CIPP model approached qualitatively. Main instruments of the research were the researchers themselves, in addition to using interview guidelines and observation sheets. Research data was obtained through interviews, observations, and documentation. Research subjects were principals, teachers responsible for implementing SSC, and coaches 17 people. Data analysis technique in this research employed data triangulation.

\section{Results and Discussion}

Implementation of SSC in SMA Negeri 1 Tanjungsari is based on the Decree of the Kepala Dinas Pendidikan Pemuda dan Olahraga of Yogyakarta Special Region No: 0651 in 2012 concerning the Grant of Operational Permits for Schools Organizing Special Excellent/Talented Education (SE/TE) for Elementary School/Junior/Senior High School. SMA Negeri 2 Playen is based on the Decree of the Kepala Dinas Pendidikan Pemuda dan Olahraga, Gunungkidul District No: 421/106/ KPTS/2013 concerning Opening of High School Local Excellence-Based Program Academic Year 2013/2014. 
Decree is a letter issued by an agency that is owned by the highest leader, which contains a statement deciding something related to the organization's regulations in question [14]. Decree issued by the agency or government agency or government service has a function for the appointed person. The function of the decree is:[14] 1) To determine / change the status/position of someone/employee/ or goods/material, 2) To form / change the status / dissolve a company, 3) To submit certain authority, to an official (delegation), 3) To authorize the entry into force of a government guideline or law. A letter of success for a SSC by the Department of Education gives full authority to schools designated to carry out sporting special classes as well as possible. Special education for special talent sports students is formal education that is organized and managed to provide educational services to students who have special talent in sports in order to be able to actualize the potential of special talents that exist in themselves so that it becomes an optimal tangible achievement [15].

Selection of new students in SSC through two stages, namely: 1) administrative selection conducted by the school, and 2) selection of sport skills and ability tests conducted by Faculty of Sport Sciences, Yogyakarta State University. Budget for operational implementation of SSC comes from the government province budgeting, school operating support, and school committees.

Factors that play a big role in actualizing talent and ability to be optimal performance and achievement are the presence of adequate facilities [16]. Facility availability or existence of SMA Negeri 1 Tanjungsari and SMA Negeri 2 Playen to support training process to improve sport performance is categorized as quite good in supporting training for several sport teams, but for individual sports is still lacking and the equipment is strongly supported by the availability of club and students themselves. Surface area owned by SMA Negeri 1 Tanjungsari is very minimal for conducting SSC.

Table 1. Surface Area Condition of Schools Organizing SSC in Gunungkidul

\begin{tabular}{llll}
\hline \hline No & \multicolumn{2}{c}{ School Name } & \multicolumn{2}{c}{ Surface Area } \\
\hline 1 & SMA Negeri & 1 & $9.900 \mathrm{~m}^{2}$ owned by school \\
& Tanjungsari & & $1.000 \mathrm{~m}^{2}$ not owned (football field and volleyball field owned by \\
& & Subdistrict Goverment) \\
2 & SMA Negeri & 2 & $30.000 \mathrm{~m}^{2}$ \\
& Playen & & \\
\hline \hline
\end{tabular}

Field facilities owned by these two schools are very minimal in order to support SSC.

Table 2. Field Facility Owned by School

\begin{tabular}{|c|c|c|c|}
\hline No & Pchool Name & Type of Field & Total \\
\hline \multirow[t]{3}{*}{1} & SMA N 1 Tanjungsari & Basketball field also used as futsal field & 1 \\
\hline & & 2. Sport Hall for badminton and sepak takraw & 1 \\
\hline & & 3. Table Tennis Field & 2 \\
\hline \multirow[t]{3}{*}{2} & SMA N 2 Playen & $\begin{array}{l}\text { 1. Basketball field also used as futsal field (2 } \\
\text { fields) and Volleyball }\end{array}$ & 1 \\
\hline & & 2. Hall for Martial Art & 1 \\
\hline & & 3. Table Tennis Field & 1 \\
\hline
\end{tabular}

Coach in SSC are all former players. Coaches have training certificates and tones that don't have. Coach as part of a sports achievement training system, is a key figure who must 
understand the correct training procedures, namely by mastering training knowledge and training methodology that contains the basic concepts of scientific applicative that can be used as a basis for conducting training activities with the lowest risk. Perhaps [17]. The Coach is a professional who helps athletes achieve maximum achievement, by making training plans in accordance with predetermined targets and targets and making evaluations of training programs that have been run [18].

Input of new students in SSC must have good quality in sports talent in certain sports. Schools actually can still find other funds to support operational funds for activities in SSC through submission of funds to business world and student guardian/parents specifically for SSC students. Fundings from guardians of volunteer SSC students by means of schools through SSC management team makes detailed budget for one year. The details of budget include all operational activities for development of sports achievements of SSC students concerning coaches' salaries, equipment, match trials both inside and outside region, official matches, food and drink, and others. SMA Negeri 1 Tanjungsari and SMA Negeri 2 Playen are more field facilities that borrow or rent to have training process to improve sport performance.

However, the condition of field facilities owned by schools itself as well as field facilities that hired or borrowed from other parties in quality manner do not support the development of better sport achievements. Schools need to immediately improve or fix the quality of sport field owned little by little, so that the field quality owned by the school is able to support good training process. Schools can borrow or rent better field facilities to support better training process. A good training process certainly needs complete training equipment support in accordance with the sports branch. The school has allocated funds every year to procure equipment. Schools need to collaborate with National Sport Committee or regional sports administrators in the procurement of training equipment. Coaches as important figure for every athlete, because without guidance and supervision from a coach, high achievement will be difficult to achieve [19]. The coach understands the principles of proper training. The trainer must have good skills and have a coach certificate.

Academic achievement development for SSC students applies the same curriculum with regular classes sourced from Education Department. Talent development training and sport performance of SSC students at SMA Negeri 1 Tanjungsari is held four times a week, while in SMA Negeri 2 Playen is held twice a week. Tryouts managed by schools for all sports are done with surrounding schools holding SSC in Yogyakarta Special Region and those outside Yogyakarta Special Region. The learning process in SSC applies regular class curriculum, especially social science programs.

Training programs for SSC students are done outside of school hours with allocation 1016 hours/week [1]. In fact the training process at SMA N 2 Playen 1 only runs once and there are two times a week. SMA Negeri 1 Tanjungsari can implement the process of increasing sport performance training 4 times a week. The training process at SMA Negeri 2 Playen twice a week, obviously very little to improve sports performance. SSC students need additional training at the club. Additional training at the club is expected to increase the amount of exercise that is lacking to improve physical condition and skills. Coaching sports achievements must be considered by many factors, including clear coaching objectives, systematic training programs, appropriate training materials and methods, and evaluations that can measure the success of the coaching process itself [20].

Many sports achievements are achieved by students in SSC, especially at district level, who always won 1st, 2nd and 3rd place winner. Provincial level achievements are still very minimal. Sport achievements from SSC from Gunungkidul Regency are very minimal. 
Academic achievement is based on score report card documents obtained in the first semester in previous school year, the Score is not much different from regular class. Graduates from the SSC of SMA Negeri 1 Tanjungsari and SMA Negeri 2 Playen are widely accepted in state and private universities. Competition as a venue for pitting several participants (teams) or competitors with the same goal (champions) according to certain rules of the game that have been set [21]. Sports achievement motivation is an objective that athletes must have to be able to excel [22]. Achievement motivation as an athlete's orientation to struggle to complete a task, persevering in facing the future, and experiencing pride in completing it [23].

\section{Conclusion}

The implementation of SSC is based on the decree from the Regent and the Head of the Education, Youth, and Sport Department of District. The implementation of SSC at the high school level in Gunungkidul Regency, so far there has been no guidebook for the implementation of SSC programs. The budget for organizing SSC still relies on the provincial budget, School Operating Support, and school committees. The condition of the availability of limited equipment and field facilities is less supportive. Coaches who handle sports (in charge) in SSC are mostly players in the sport they are training/mastering. Many coaches do not have coach certificate, and not from sports coaching graduates. Improvement of academic performance of SSC students use the same curriculum with regular classes sourced from the Education Department. The training process is carried out 2-4 times a week. Sports achievements at Gunungkidul district are good. Academic achievement is quite good.

Acknowledgments. The author would like to thank the headmaster of SMA Negeri 1 Tanjungsari and SMA Negeri 2 Playen in Gunungkidul Regency, Yogyakarta Special Region for giving research permission in a special sports class in 2018 . 


\section{Reference}

[1] Kementrian Pendidikan Nasional.: Panduan Pelaksanaan Program Kelas Olahraga. Jakarta: Direktorat Jenderal manajemen Pendidikan Daar dan Menengah, Direktorat Pembinaan Sekolah Menengah Pertama (2010)

[2] Knowles, O., Gastin, Paul B. \& Kremer, P.: Time Use and Health and Wellbeing Outcomes of Sport School Students in Australia. Journal Sport Sci Health (2017)

[3] Emrich, E., at el.: Evaluation of the Elite Schools of Sport. (2009). Empirical Findings From an Individual and Collective Point of View. Article in International Review for the Sociology of Sport. 44/2-3 151-171

[4] Sari, H. P., Handayani, O. W. K., \& Hidayah, K. (2017). Evaluasi Program Pembinaan Atlet Pekan Olahraga Nasional Cabang Olahraga Bulu Tangkis Sumatera Selatan. Journal of Physical Education and Sports 6(3): $261-265$

[5] Pratama, D. S., Rahayu, T., \& Yudha Kusuma, D. W. (2017). Pengaruh Metode Latihan dan Panjang Tungkai Terhadap Hasil Servis Pada Atlet Sepaktakraw Kabupaten Demak. Journal of Physical Education and Sport. 6(3): 236 - 240

[6] Pakaya, R., Rahayu, T., \& Soegiyanto, KS. (2012). Evaluasi Program Pada Klub Bola Voli Kijang di Kota Gorontalo". Journal of Physical Education and Sport,1(2): 139-145.

[7] Satria, M. H., Rahayu, T., \& Soegiyanto, KS. (2012). Evaluasi Program Pembinaan Olahraga Sepakbola di sekayu Youth Soccer Academy (SYSA) Kabupaten Musi Banyuasin Sumatera Selatan. Journal of Physical Education and Sports 1 (2): 161 - 167

[8] Kristiansen, E., \& Houlihan, B. (2015). Developing young athletes: The role of private sport schools in the Norwegian sport system. Journal: International Review for the Sociology of Sport. 123.

[9] Kendellen, K., \& Camiré, M. (2015). Examining Former Athletes' Developmental Experiences in High School Sport. Journal Sage Open, Oktober-Desember: 1 - 10.

[10] McGuine, Timothy A., at el. (2017). A Prospective Study on the Effect of Sport Specialization on Lower Extremity Injury Rates in High School Athletes. The American Journal of Sports Medicine, Vol. XX, No. X

[11] Malisoux, L., at el. (2012). Injury incidence in a sports school during a 3-year follow-up. Jurnal Sports Medicine DOI 10.1007/s00167-012-2185-1

[12] Wijayati, E., Soegiyanto, \& Rahayu. S. (2015). Evaluasi Program Pembinaan Olahraga Sepaktakraw Pengurus Persatuan Sepaktakraw Indonesia Kabupaten Jepara. Journal of Physical Education and Sports 4 (1): 93 - 98.

[13] Camiré, M., Forneris, T., \& Trudel, P. (2012). High School Sport Stakeholders' Perspectives on Coaches' Ability to Facilitate Positive Youth Development. Journal of coaching Education. Volume 5, Issue 1 May 2012 (64-82)

[14] Simmamora, L. S. (2015) Surat Keputusan (SK). https://www.smkdamosdiary.com/2015/05/ surat-keputusan.html. (downloaded, 11 Juni 2019).

[15] Khodari, k. 2016. Evaluasi Program Pendidikan Kelas Khusus Olahraga Sekolah Menengah Atas Negeri 1 Sewon Bantul Yogyakarta". Jurnal Pendidikan Jasmani dan Olahraga. Volume 15, No. 2 (123-132)

[16] Ahmad, Adib A., \& Nurhikmahyanti, D. (2014). Hubungan Motivasi Belajar Olahraga dan Sarana Prasarana Keolahragaan Terhadap Prestasi Belajar Siswa Cabang Olahraga Voli Pantai di UPT SMA Negeri Olahraga Provinsi Jawa Timur. Jurnal Inspirasi Manajemen Pendidikan, Vol. 3 No. $3,(66-71)$

[17] Irianto, Djoko P. (2002). Dasar Kepelatihan. Yogyakarta: Universitas Negeri Yogyakarta

[18] Ghozali, P., Sulaiman \& Pramono, H. 2017. Pembinaan Olahraga Sepakbola di Klub Indonesia Muda Purwokerto Kabupaten Banyumas. Journal of Physical Education and Sport,6(1): (76-82)

[19] Harsono. (2015). Kepelatihan Olahraga Teori dan Metodologi. Bandung: PT Remaja Rosdakarya

[20] Andriani, A., Nasuka \& Irawan, Fajar A. (2019). Coaching Evaluation for Women's Volleyball Sports Year 2018 Semarang City. Journal of Physical Education and Sports 8 (1): (11 - 18) 
[21] Gema, A. R., Rumini, \& Soenyoto, T. (2016). Manajemen Kompetisi Sepakbola Sumsel Super League Kota Palembang. Journal of Physical Education and Sport, 5(1): 8- 16).

[22] Muskanan, K. (2015). Analisis Motivasi Berprestasi Atlet Pusat Pendidikan dan Latihan Olahraga Pelajar (PPLP) Provinsi Nusa Tenggara Timur. Jurnal Kebijakan \& Administrasi Publik Vol 19 No 2. (105 - 113)

[23] Komarudin. (2015). Psikologi Olahraga latihan keterampilan mental dalam Olahraga Kompetitif. Bandung: PT Remaja Rosdakarya Offset 